\title{
Injuries treated in hospital among urban and rural inhabitants of eastern Poland
}

\author{
Marek Kos ${ }^{1,2}$, Bartłomiej Drop², Agnieszka Dziewa', Marian Jędrych ${ }^{3}$ \\ ${ }^{1}$ Independent Public Health Care Unit in Kraśnik \\ ${ }^{2}$ Medical University of Lublin, II Faculty of Medicine with the English Division, Department of Public Health, Poland \\ ${ }^{3}$ Department of Mathematics and Biostatistics, Medical University, Lublin
}

Kos M, Drop B, Dziewa A, Jędrych M. Injuries treated in hospital among urban and rural inhabitants of eastern Poland. Ann Agric Environ Med. 2017; 24(3): 507-512. doi: 10.5604/12321966.1232552

\begin{abstract}
Abstarct longest for hip and thigh injuries (11.86 days). on weekdays and in the morning.

\section{Key words}

injuries, hospitalization, county, rural municipality, township
\end{abstract}

Introduction and objective. Injuries are a serious medical and social problem, especially when accompanied by distant or deferred effects, often causing serious dysfunctions and permanent disability for life. The study aimed at presenting the incidence of injuries of urban and rural population treated in a district hospital in eastern Poland.

Material and Methods. The study was carried out in the Independent Public Health Care Institution in Kraśnik in 2011 among patients hospitalized in the Department of Trauma Surgery and Orthopedic Unit who sustained injuries. Medical records of 795 patients - 326 women and 469 men, aged 10-99 years, were analyzed.

Results. During the period considered among those hospitalized due to injuries, men (59\%), those aged 50-59years (19.0\%), and living in rural areas (72.7\%) predominated. Injuries most commonly affected the head (18.87\%), elbow and forearm $(16.86 \%)$, knee and lower leg (16.60\%), and the hip and thigh (13.96\%). Average hospital stay was 5.65 days and was the

Conclusions. Injuries occurred most frequently in the population of patients living in rural areas, often among men, usually

\section{INTRODUCTION}

Injuries sustained because of accidents are one of the biggest problems of modern medicine. According to the literature, the consequences of injuries are the second leading cause of disability and the third leading cause of death after cardiovascular diseases and cancers. The number of injuries is increasing as a result of lifestyle changes, conditions of work, and striving to move from place to place as soon as possible $[1,2,3,4]$.

The causes of injuries worldwide are dominated by road accidents. In Poland, the most common cause is falling from heights (60\%), including in rural areas frequent falls from a height during field work. Injuries while jumping into the water are also frequent, which usually involve the cervical spine. Car accidents account for $15 \%$ of injuries and motorcycle accidents for $6 \%$. Over time, the number of injuries caused by traffic accidents increases and the number of falls associated with work is reduced. One group of injuries includes damages of spine and spinal cord, often causing serious disability and lifelong permanent dysfunction. This is all the more severe, the more it concerns younger people. According to epidemiological data, $8-15 \%$ of the world population experiences different types of injuries a year. The number of fatalities exceeds 5 million a year. There has also been an increase in the proportion of post-injury disabilities, which ranges from $10-30 \%[5,6,7,8]$.

Injuries resulting from accidents in developed countries constitute a growing health, social and economic problem

Address for correspondence: Marek Kos, Independent Public Health Care Unit in Kraśnik, Poland

E-mail: marekkos@op.pl

Received: 12 April 2014; accepted: 10 July 2014; first publuished: February 2017 (high cost of treatment and rehabilitation of victims of accidents). In Poland, the number of deaths due to injury and poisoning is $26,000-28,000$ a year. Every year there occur more than:

- 50,000 road accidents, in which more than 5,000 individuals are killed, 60,000-70,000 persons are injured. In Poland, 11 people are killed per 100 accidents, against an average rate of 3.5 in EU countries.

- 86,000 accidents at work, including 500 deaths and 1,000 serious accidents.

- 145,000 accidents of students at schools, including 90 deaths and 1.2,000 serious cases.

In the last $10-15$ years, numerous countries have implemented prevention programmes targeted at selected groups of accidents, social environment or age groups. Visible successes have been achieved by coordinating all efforts in this regard, as well as by public education, and recognition of the role of psychological and environmental factors in the causes of accidents.

The experiences of the last decade point to the need not only to prevent injuries arising from accidents, but also to the promotion of safety. Hence, activities in this area are reflected in the National Health Programme for the years 2007-20015 as the 'Strategic Objective 3 Reduction in the incidence of injuries caused by accidents and limiting their consequences.'

It assumes achieving the following effects of the implementation of the strategic objective:

1. Gradual reduction of the number of injuries caused by accidents and the number of victims.

2. Decrease in the proportion of deaths due to injuries because of road accidents.

3. Reducing the number of injuries resulting from accidents at work by the data of mid-year 2005. 
4. Reducing the number of injuries resulting from accidents at school at least by the data of mid-year 2005.

5. Undertaking activities and research works to introduce a record of injuries because of accidents at home.

6. Undertaking activities and research works to introduce a record of injuries because of accidents at leisure (in recreation and sport places) [9].

\section{OBJECTIVES}

The study aimed at presenting the type and incidence of injuries among an urban and rural population treated in a district hospital in eastern Poland.

The following specific issues were suggested:

1. Does the trauma incidence among the inhabitants of the county depend on gender?

2. What is the most common location of injury?

3. Does the type of injury depend on the place of residence?

4. Is the incidence of injuries environmentally-differentiated?

5. Does the day of the week and time of day have an impact on the incidence of injuries?

6. What affects the length of hospitalization due to injury?

\section{MATERIALS AND METHOD}

The study was carried out in 2011 at the Independent Public Health Care Institution in Kraśnik. The survey covered patients hospitalized in the Department of Trauma Surgery with Orthopedics Unit, who experienced injuries. Injuries incurred on weekdays and holidays were analyzed, together with division into time of day: morning (06.00-14.00), afternoon (14.00-22.00) and night (22.00-8.00).

Patients were the inhabitants of 10 municipalities of the Kraśnik Countyt, of which 8 were rural communities, one urban municipality and one urban-rural, as well as 2 towns and 206 rural localities. Rural municipalities included Dzierzkowice, Gościeradów, Kraśnik, Trzydnik Duży, Szastarka, Urzędów, Wilkołaz, Zakrzówek. The town of Kraśnik constituted the urban municipality. The analyzed urban-rural municipality is the town and municipality of Annopol. In this case, the inhabitants residing in the town of Annopol were separated from the inhabitants of rural areas of the municipality. According to the Statistical Office in Lublin, in 2012, the county had a population of 99,137 inhabitants, of which 50,778 were women (51.2\%). The rural areas were inhabited by 46,647 people, including $50.9 \%$ of women. The urban and urban-rural communities were inhabited by 52,490 persons ( $52 \%$ women), including in the 2 towns 38,319 inhabitants [10].

The statistical results (after calculating percentage) are presented in the Tables and Figures. In statistical analysis statistical hypotheses verification was used based on nonparametric tests: U Personn-Whitney test and Pearson Chi^, $\mathrm{p}$ Fisher exact test, bilateral. Significance of the relationships between the studied parameters were found at $\mathrm{p}<0.05[11$, 12]. Analysis of the research results was performed on an IBM PC, using STATISTICA 10.0.

Medical records of 795 patients - 326 women (41\%) and 469 men (59\%) aged 10-99 years, were analyzed. The highest proportion were patients aged 50-59 years (19\%) (Fig. 1).
Patients with injuries hospitalized in the Independent Health Care Centre in Kraśnik were people living in the urban $-27.3 \%$ (217 patients) and rural municipality - 72.7\% (578 patients).

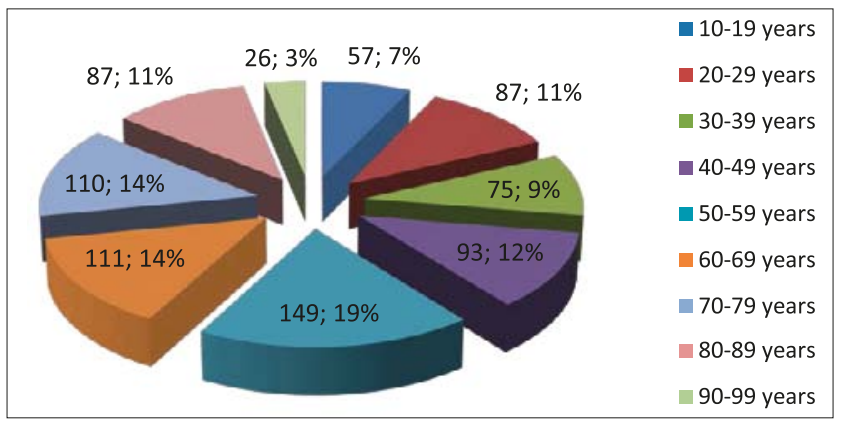

Figure 1. Age distribution of patients

\section{RESULTS}

The medical records of 795 patients - 326 women (41\%) and 469 men (59\%), were analyzed. There was a statistically significant difference in the number of injuries in men $(\mathrm{u}=5,072 ; \mathrm{p}<0,001)$.

Table 1. Location of injuries in the population according to gender

\begin{tabular}{|c|c|c|c|c|}
\hline \multirow{2}{*}{ Injury } & & \multicolumn{2}{|c|}{ Gender } & \multirow{2}{*}{ Total } \\
\hline & & Males & Females & \\
\hline \multirow{2}{*}{ Head } & Number & 102 & 48 & 150 \\
\hline & $\%$ & $21.75 \%$ & $14.72 \%$ & $18.87 \%$ \\
\hline \multirow{2}{*}{ Neck } & Number & 10 & 7 & 17 \\
\hline & $\%$ & $2.13 \%$ & $2.15 \%$ & $2.14 \%$ \\
\hline \multirow{2}{*}{ Chest } & Number & 20 & 11 & 31 \\
\hline & $\%$ & $4.26 \%$ & $3.37 \%$ & $3.90 \%$ \\
\hline \multirow{2}{*}{$\begin{array}{l}\text { Abdomen, lower back, pelvic and } \\
\text { lumbar spine }\end{array}$} & Number & 47 & 37 & 84 \\
\hline & $\%$ & $10.02 \%$ & $11.35 \%$ & $10.57 \%$ \\
\hline \multirow{2}{*}{ Shoulder and arm } & Number & 53 & 24 & 77 \\
\hline & $\%$ & $11.30 \%$ & $7.36 \%$ & $9.69 \%$ \\
\hline \multirow{2}{*}{ Elbow and forearm } & Number & 60 & 74 & 134 \\
\hline & $\%$ & $12.79 \%$ & $22.70 \%$ & $16.86 \%$ \\
\hline \multirow{2}{*}{ Wrist and hand } & Number & 53 & 6 & 59 \\
\hline & $\%$ & $11.30 \%$ & $1.84 \%$ & $7.42 \%$ \\
\hline \multirow{2}{*}{ Hips and thighs } & Number & 35 & 76 & 111 \\
\hline & $\%$ & $7.46 \%$ & $23.31 \%$ & $13.96 \%$ \\
\hline \multirow{2}{*}{ Knee and lower leg } & Number & 89 & 43 & 132 \\
\hline & $\%$ & $18.98 \%$ & $13.19 \%$ & $16.60 \%$ \\
\hline \multirow{2}{*}{ Total } & Number & 469 & 326 & 795 \\
\hline & $\%$ & $100.0 \%$ & $100.0 \%$ & $100.0 \%$ \\
\hline
\end{tabular}

Pearson $\mathrm{Chi}^{2}: 81.6938, \mathrm{df}=8, \mathrm{p}=0.000000$

Most of diagnosed injuries were to the head (18.87\%), elbow and forearm (16.86\%), knee and lower leg (16.60\%). Among women, injuries of hip and thigh (23.31\%), elbow and forearm (22.70\%) dominated; in men - the head (21.75\%), knee and lower leg (18.98\%) (Tab. 1). A significant difference in women (23.31\%) and men (7.46\%) was recorded in injuries to the hip and thigh. 
In the urban municipality, the most common injuries involved the head (20.28\%), elbow and forearm, knee and lower leg (15.67\% each), abdomen, lower back, lumbar spine and pelvis (14.75\%), hip and thigh (14.29\%), and shoulder and $\operatorname{arm}(12.44 \%)$. The least frequently diagnosed injuries concerned the neck and chest (1.38\%).

In rural areas, the most numerous injuries involved the head (18.34\%), elbow and forearm (17.30\%), knee and lower leg (16.96\%), and hip and thigh (13.84\%). The results were statistically significant ( $\mathrm{p}=0,021385)$.

The most common injuries occurring on weekdays and holidays, respectively, were injuries of the head $(19.34 \%$, $17.37 \%)$, knee and lower leg (17.69\%, 13.16\%), elbow and forearm (16.86\%, 16.84\%), hip and thigh (13.22\%, 16.32\%). The differences were not statistically significant $(\mathrm{p}=0.421809)$.

At night, the most numerous injuries involved the head $(34.43 \%$,$) knee and lower leg (18.03 \%)$. In the morning, the most frequent were the injuries of elbow and forearm (21.18\%), knee and lower leg (17.73\%), while at midday the most common injuries included head (19.82\%), the hips and thighs (15.24\%). There was a significant correlation between time of day and type of injury $(p=0,006765)$.

The longest period of hospitalization (8- 2 person-days) concerned injuries of the hip and thigh (64.86\%). In the time frame of 4-7 person-days, these were injuries of the abdomen, lower back, lumbar spine and pelvis (41.67\%), 2-3 person-days - neck injuries (58.82\%), and $0-1$ person-days injuries of the elbow and forearm (58.96\%). The differences were statistically significant $(\mathrm{p}=0,00000)$.

Injuries to the hip and thigh were characteristic for the elderly with an average age of 75.86 years, and injuries of wrist and hand for the youngest with an average age of 38.88 years. Other injuries with average ages of patients are shown in Figure 2. Significant differences were found between the average age of the patients and the injuries $(\mathrm{p}<0.01)$.

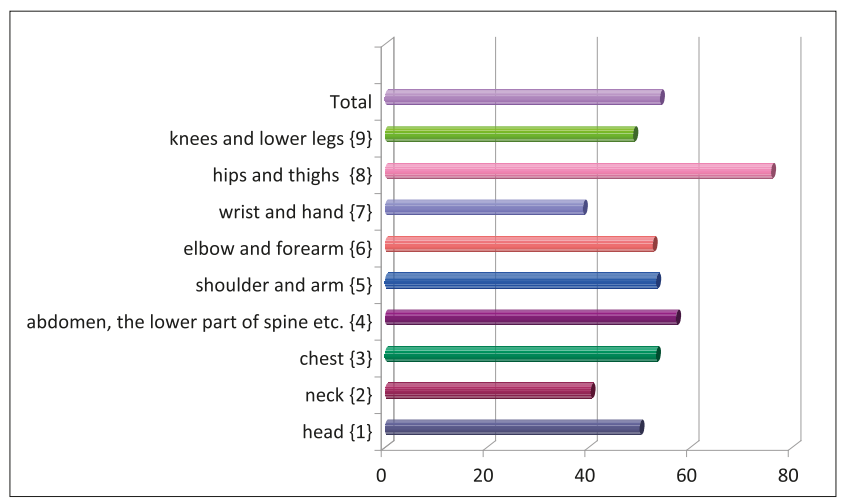

Figure 2. Mean age of patients depending on the type of injury

Total person-days of hospitalization due to injury ranged from 1-82. The largest group comprised 206 patients treated for $0-1$ person-days (25.91\%), and for 2-3 person-days, 204 people $(25.66 \%)$. The distribution of person-days of hospitalization in men and women was similar. Length of stay for men was $0-1$ and $2-3$ person-days (25.80\% each), while the women's stay in the ward usually lasted $0-1$ persondays $(26.07 \%)$.

There was no significant relationship between the number of person-days and gender $(\mathrm{p}=0.988480)$.

The time of hospitalization of the rural residents was mainly in the range $0-1$ person-days (26.64\%), while of those living in the town - 4-7 person-days (25.81\%). Distribution of the number of person-days of hospitalization in the urban and rural municipality was close. There was no significant relationship between the number of person-days of hospital stay and the type of municipality ( $p=0,798734)$.

The longest duration of hospitalization, $8-82$ person-days, was for patients aged over 90 years. This concerned $50.00 \%$ of patients in the age group 90-99 years. Other relationships between the time of hospitalization and age groups of patients are presented in Table 2. There was a significant correlation between the number of person-days of hospital stay and age $(\mathrm{p}=0.000000)$.

Table 2. Number of person-days of hospitalization, depending on the age of the patients

\begin{tabular}{|c|c|c|c|c|c|}
\hline \multirow[b]{2}{*}{ Age } & \multicolumn{4}{|c|}{ Person-days } & \multirow[b]{2}{*}{ Total } \\
\hline & $\begin{array}{c}\text { 0-1 } \\
\text { person- } \\
\text { days }\end{array}$ & $\begin{array}{c}2-3 \\
\text { person- } \\
\text { days }\end{array}$ & $\begin{array}{c}\text { 4-7 } \\
\text { person- } \\
\text { days }\end{array}$ & $\begin{array}{c}8-82 \\
\text { person-days }\end{array}$ & \\
\hline \multirow[t]{2}{*}{$\begin{array}{l}10-19 \\
\text { years }\end{array}$} & 26 & 19 & 11 & 1 & 57 \\
\hline & $45.61 \%$ & $33.33 \%$ & $19.30 \%$ & $1.75 \%$ & $7.17 \%$ \\
\hline \multirow[t]{2}{*}{$\begin{array}{l}20-29 \\
\text { years }\end{array}$} & 23 & 33 & 18 & 13 & 87 \\
\hline & $26.44 \%$ & $37.93 \%$ & $20.69 \%$ & $14.94 \%$ & $10.94 \%$ \\
\hline \multirow[t]{2}{*}{$\begin{array}{l}30-39 \\
\text { years }\end{array}$} & 19 & 22 & 20 & 14 & 75 \\
\hline & $25.33 \%$ & $29.33 \%$ & $26.67 \%$ & $18.67 \%$ & $9.43 \%$ \\
\hline \multirow[t]{2}{*}{$\begin{array}{l}40-49 \\
\text { years }\end{array}$} & 22 & 25 & 24 & 22 & 93 \\
\hline & $23.66 \%$ & $26.88 \%$ & $25.81 \%$ & $23.66 \%$ & $11.70 \%$ \\
\hline \multirow[t]{2}{*}{$\begin{array}{l}50-59 \\
\text { years }\end{array}$} & 38 & 42 & 33 & 36 & 149 \\
\hline & $25.50 \%$ & $28.19 \%$ & $22.15 \%$ & $24.16 \%$ & $18.74 \%$ \\
\hline \multirow[t]{2}{*}{$\begin{array}{l}60-69 \\
\text { years }\end{array}$} & 32 & 25 & 30 & 24 & 111 \\
\hline & $28.83 \%$ & $22.52 \%$ & $27.03 \%$ & $21.62 \%$ & $13.96 \%$ \\
\hline \multirow[t]{2}{*}{$\begin{array}{l}70-79 \\
\text { years }\end{array}$} & 32 & 20 & 27 & 31 & 110 \\
\hline & $29.09 \%$ & $18.18 \%$ & $24.55 \%$ & $28.18 \%$ & $13.84 \%$ \\
\hline \multirow[t]{2}{*}{$\begin{array}{l}80-89 \\
\text { years }\end{array}$} & 11 & 14 & 22 & 40 & 87 \\
\hline & $12.64 \%$ & $16.09 \%$ & $25.29 \%$ & $45.98 \%$ & $10.94 \%$ \\
\hline \multirow[t]{2}{*}{$\begin{array}{l}\text { 90-99 } \\
\text { years }\end{array}$} & 3 & 4 & 6 & 13 & 26 \\
\hline & $11.54 \%$ & $15.38 \%$ & $23.08 \%$ & $50.00 \%$ & $3.27 \%$ \\
\hline Total & 206 & 204 & 191 & 194 & 795 \\
\hline
\end{tabular}

Pearson Chi $^{2}: 74.5245, \mathrm{df}=24, \mathrm{p}=0,000000$

The highest average number of person-days was recorded for people with injuries to the hip and thigh. Other types of injury hospitalization time is shown in Figure 3. There were significant differences between the number of person-days and injuries suffered in these locations $(p=0,0000)$. Average length of hospital stay of women was longer than for men (5.91 and 5.47 person-days, respectively) $(\mathrm{p}=0,7204)$.

Average length of hospital stay of rural residents was shorter than those living in the town (5.83 person-days) and amounted to 5.59 person-days $(\mathrm{p}=0,2250)$. There were no statistically significant differences. 
Persons who suffered an injury on a weekday were hospitalized for a shorter time (5.48 person-days) than those who experienced an injury in holiday time (6.22 person-days). There were no statistically significant differences $(p=0,1660)$.

The average stay in hospital after injuries suffered at night was the longest and amounted to 6.75 person-days, followed by injuries sustained in the morning, which was the the shortest (4.89 person-days). The differences were statistically significant $(\mathrm{p}=0,0003)$.

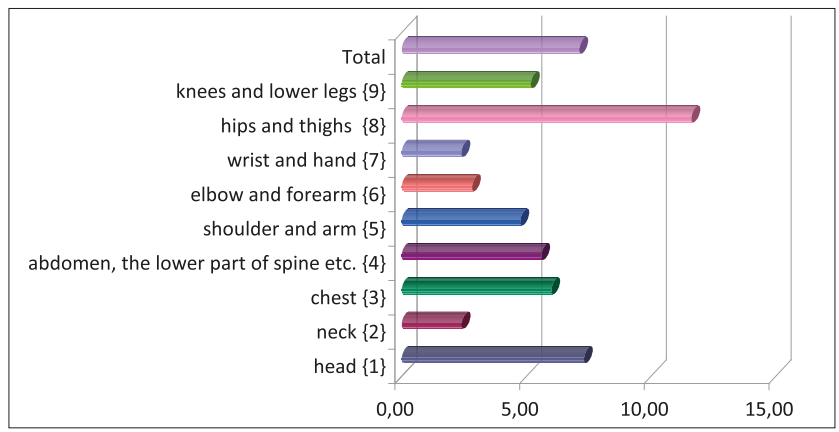

Figure 3. Number of person-days of hospitalization, depending on type of injury

The analysis found that the injuries occurred most frequently in the morning in $51.07 \%$ of cases; slightly fewer injuries took place at midday $(41.26 \%)$, while $7.67 \%$ of the patients suffered an injury at night. In both women (49.39\%) and men (52.24\%), most injuries occurred in the morning. The prevailing occurrence of injuries was observed at midday in females (46.63\%), compared with injuries in men (37.53\%), as opposed to injuries occurring during the night $(10.23 \%$ males; $3.99 \%$ - females). There was a significant correlation between the occurrence of injuries at these times of day and gender $(p=0,000937)$.

Injuries that occurred in the morning mainly concerned people with an average age of 55.26 years. The age of the person suffering injuries in the night was 41.87 years, and injuries occurring during the day were observed in patients with an average age of 54.74 years. The differences were statistically significant ( $\mathrm{p}=0,00003)$.

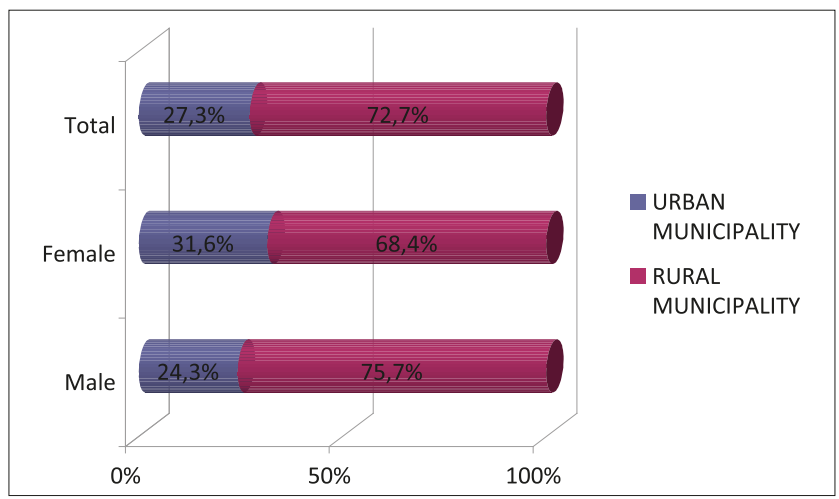

Figure 4. Distribution of injuries according to patients' gender and place of residence.

In higher proportion injuries occurred among residents of rural $(72.70 \%)$ than urban $(27.30 \%)$ municipality. In the countryside injuries more often concerned men $-75.69 \%$, in the town -women - $31.60 \%$. There was a significant correlation between the type of municipality and gender ( $p$ $=0,023280$ ) (Fig. 4).
Injuries occurred more frequently on weekdays $(76.10 \%)$ than holidays $(23.90 \%)$, in both men $(75.69 \%)$ and women (76.69\%). The distribution of injuries in the examined days in men and women was similar. There was no significant relationship between the day of occurrence of injury and gender $(p=0,7464)$.

There was no significant relationship between the day of occurrence of injury and the municipality ( $p=0,337438)$. Injuries happened much more often on weekdays $(76.10 \%$ : 605 people), both in rural residents $(76.99 \%)$ and town residents $(73.73 \%)$. Similarly, there was no significant relationship between time of day when the injury occurred and the municipality $(\mathrm{p}=0,7464)$. Most injuries occurred in the morning (51.07\%). The distribution of injuries in the morning in the urban and rural municipality was similar (50.69\% and $51.21 \%$, respectively). The smallest percentage of injuries for both types of municipalities was reported during the night (7.67\%). In the rural municipality, injuries happened slightly more frequently in the morning and at night, compared with the urban municipality.

\section{DISCUSSION}

The number of accidents at work in rural areas is very high and accounts for about $39 \%$ of cases related with work, and fatal accidents are up to $48 \%$ of all fatal accidents at work [13]. According to data from the Polish Agricultural Social Insurance Fund (KRUS), in 1995-1997, there was a significant increase in the frequency of accidents on farms. In 1995, the rate was 27.9/1,000 insured, in 1996 it rose to 28.4, and in 1997 to 29.3. Data on accidents in agriculture vary by provinces. With the national average in 1997 of 29.2 cases/1,000 insured, in the old provinces of the mid-eastern region this ratio exceeded 40/1000. According to the State Labor Inspectorate, most, i.e. $75 \%$ of serious accidents and $55 \%$ of fatalities, took place directly in the farmyard $[14,15]$.

Research conducted by Bartoszcze-Tomaszewska on a population of patients with injuries of the facial skeleton, working on farms accounted for a significant percentage of injuries among males (91.2\%), with the highest accident rate observed in the youngest group of respondents - 18-40 yearolds (44.9\%). The mean age of all patients was 44.4 years [16].

This is also confirmed in the studies of the authors of this article $-75.69 \%$ of rural men were subject to injuries, mainly aged $20-39$ years (20\%). The mean age of hospitalized patients was 54.02 years [16].

The results obtained in the 6th Military Hospital with Outpatient Clinic in Deblin, Poland, on the basis of information on patients hospitalized due to injuries, indicate that males were the majority in this group (66.3\%). People aged $40-60$ years accounted for the largest age group (37.2\%), followed by $20-40$ year-olds (24\%), $18-20$ year-olds (13.7\%), the least numerous group of persons were aged over 80 (2 $\%)$. The average age was 45 years: females - 53 years, males - 39.7 years.

Most injuries were caused by falls (37.7\%), traffic accidents (21.9\%), associated with the practicing of sport (11.7\%), fights and beatings (9.18\%), and a fall from a height (7.14\%).

Injuries most often concerned to the upper and lower limbs (26\%), forearm, knee and hand. Injuries to the head (22.9\%), chest (6.1\%) and shoulder (5.1\%). The most common injuries confirmed by clinical diagnoses were fracture of 
the forearm (13.3\%), lower leg, including ankle joint (9.2\%), superficial injuries involving multiple body regions (8.7\%), superficial head injury (7.1\%) internal damage to the knee joint $(6.6 \%)$ [17].

The material of authors of this article indicates a high similarity with the research results presented in the literature in terms of gender, age and area of the body which concerned the injury.

The most serious typical fractures in the elderly were fractures of the proximal femur. Although in most cases these were less complicated than fractures in young people, the mortality rate associated with them exceeded $20 \%$, while in people under 55 years of age, the mortality rate varied between $2.3-6.0 \%$. More than $50 \%$ of elderly patients did not regain the physical fitness they had before the accident, and a part of them experienced fractures again in the same location $[18,19,20,21,22,23,24]$.

The results obtained in the presented study confirm the occurrence of the most common injuries in the hip and thigh region $(11.62 \%)$ in patients in the group above 70 years of age.

Falls are the leading cause of injuries, post-traumatic complications and associated mortality in the elderly. The falls occur at least once a year in $30 \%$ of people over 65 years, in $40 \%$ of those over 80 years of age, and in $50 \%$ of people above 90 years of age. In half of the cases, falling results in injury, including severe injury in $10-15 \%$ of patients (bone fractures, head or cervical spine injury). Most falls occur in the course of normal life activities. This is due to the deteriorating overall mobility, visual impairment, and impaired balance due to old age, and sometimes as the result of co-morbidities or the effect of a medication. For similar reasons, and because of the extended reaction time, older people often become the perpetrators or victims of traffic accidents, which are another common cause of injury [22, $23,24,25,26,27]$.

The current study on a population of patients from Kraśnik hospital demonstrates that the majority of injuries (54.02\%) involved patients over 50 years of age. Among them, the most numerous in this age group were injuries of abdomen and spine (57.18\%), shoulder and arm (53.27\%) and elbow and forearm (52.61\%). In patients over 70 years of age, hip and thigh injuries dominated (75.86\%).

Statistical studies indicate that in Poland in 2000, people over 65 years of age accounted for $12.3 \%$ of the total population, while in the cities the index reached $11.7 \%$, in rural areas $13.3 \%$. Forecasts of the Central Statistical Office show that in 2020 the proportion of people over 60 is expected to reach $22.4 \%$. Other reports indicate that approximately $60 \%$ of patients over 65 years of age suffer falls in institutionalized care units due to chronic diseases in hospitals, care facilities or nursing homes. Each fall, in addition to physical injury, triggers psychological adverse effects: anxiety, depression, tendency to limitations, and thus little physical activity. In approximately $20 \%$ of patients there develops the socalled 'injury syndrome', which is manifested by anxiety and difficulties in carrying out everyday activities. According Wojszel and Bien, in the case of hip fractures $(90 \%$ is the consequence of a fall), half of the patients lose the ability to walk. Falls are the leading cause of death among fatalities due to unfortunate accidents in patients over 65 years of age [28].

Spinal injuries are not as common as injuries of the limbs and the skull, but their number is steadily increasing. The number of spinal cord injuries is estimated at 25-35 people per million population, half of which is damage to the cervical spine. The injuries concern men 5-6-fold more frequently than women. In developed countries, the incidence of transverse spinal trauma caused by injury is estimated at over 10 million inhabitants per year.

In Poland, the number of injuries of the cervical spine with spinal cord injury is estimated at about 300 per year. Spine injuries are the most common in people aged $21-40$ years. In the city, these are often young people (65\%) aged up to 40 years of age, older people in rural areas (31\%) over 60 years of age. Injuries in the city are more often associated with traffic accidents, in the countryside - with work in agriculture. Injuries in the younger age group are associated with traffic accidents and sports, and in the older age group often are associated with falls from a height and crushing. Overall, traffic accidents are assumed to be the most common cause of spinal injuries, constituting $33-75 \%$. The next place is occupied by falls from a height (12-44\%), followed by sports injuries (3.5-18\%). Most vertebral fractures occur in the upper lumbar spine section or on the border of the thoracic and lumbar spine [29].

The analysis carried outin the presented study proves that spine injuries were the fifth group $(10.57 \%)$ for the frequency of injuries incidence. They occurred more frequently in women $(11.35 \%)$ than in men $(10.02 \%)$, more often in people living in the town $(14.75 \%)$ than in rural areas $(9.00 \%)$.

\section{CONCLUSIONS}

1. Analysis of medical records shows that injuries occurred more often in men.

2. Most injuries related to the hip and thigh in women, and the head in men.

3. The same types of injuries dominated in both the urban municipalities and rural areas.

4. Most injuries occurred in the population living in rural areas (75\% of all injuries).

5. Injuries occurred most frequently on weekdays (75\% of injuries), in the morning (50\% of cases).

6. The time of hospitalization due to injury depended on the type of injury and the patient's age.

\section{REFERENCES}

1. Bartoszcze-Tomaszewska M, Tomaszewski T, Woronko P, Stodółkiewicz A, Wojciechowicz J. Epidemiologiczna ocena obrażeń czaszki twarzowej spowodowanych wypadkami przy pracy w regionie lubelskim. Czas Stomatol. 1998; 51: 474-478.

2. Hubert E, Szarmach J, Grabowska S, Piotrowski L, Preferansow J. Przyczyny i następstwa urazów części twarzowej czaszki powstałych na skutek wypadków w pracy w makroregionie północno-wschodnim. Med Pr. 1995; 46: 247-254.

3. Polakowska B. W sprawie orzekania o zdolności do pracy osób po przebytych urazach czaszkowo-mózgowych. Med Pr. 1990; 41: 348-352.

4. Karski JB. Profilaktyka urazów w świetle działań Światowej Organizacji Zdrowia i Unii Europejskiej. III Międzynarodowa Konferencja Naukowa - Epidemiologia chorób niezakaźnych w Polsce - ich następstwa zdrowotne i społeczne. Problemy definiowania niepełnosprawności; May 27-28 2004; Puławy, Poland; Lublin, 2004.

5. Karski JB. Wypadki, urazy i zatrucia. Dane statystyczne. Zdr Publ. 1999; CIX(11): 409-416.

6. Białoszewski D, Słupik A, Lewczuk E, Gotlib J, Mosiołek A, Mierzwińska A. Incidence of falls and their effect on mobility of individuals over 65 years of age relative to their place of residence. Ortop Traumatol Rehabil. 2008; Sep-Oct;10(5): 441-8. 
7. Łabęcka M, Lorkiewicz-Muszyńska DE, Przystańska A, Kondrusiewicz $\mathrm{K}$. Injuries due to human and animal aggresion in humans. Ann Agric Environ Med. 2013; 20(1): 91-95.

8. Sygit K, Nasiłowska-Barud A, Karwat ID, Gorczyca R, Jędrych M, Kołłątaj W. Selected social and health problems in functioning of disabled rural and urban inhabitants in the Lublin Region - similarities and differences. Ann Agric Environ Med. 2010; 17: 287-299.

9. Narodowy Program Zdrowia na lata 2007-2015. Załącznik do Uchwały Nr 90/2007 Rady Ministrów z dnia 15 maja 2007r. http://www.mz.gov. pl/__data/assets/pdf_file/0020/12494/zal_urm_npz_90_15052007p. pdf (access: 2014.05.07)

10. Statystyczne Vademecum Samorządowca 2013. http://lublin.stat. gov.pl/vademecum/vademecum_lubelskie/portret_wojewodztwa/ wojewodztwo_lubelskie.pdf (access: 2014.05.07)

11. Armitage P. Metody statystyczne w badaniach medycznych. PZWL, 1978.

12. Sawicki F. Elementy statystyki dla lekarzy. PZWL, 1982.

13. Wiraszka R. Wypadkowość w rolnictwie indywidualnym na terenie województwa radomskiego w 1996 roku na podstawie materiału orzeczniczego KRUS. Med Og. 1998; 33: 183-194.

14. Wypadki przy pracy i choroby zawodowe rolników oraz działalność prewencyjna KRUS w 2005 roku. KRUS, 2006. http://www.krus.gov. $\mathrm{pl} /$ fileadmin/moje_dokumenty/dokumenty/prewencja/raporty/2005/ Wypadki_przy_pracy.pdf (access: 2014.05.07)

15. Personiecka-Bryła I, Pikala M, Bryła M. Health inequalities among rural and urban inhabitants of Łódz Province, Poland. Ann Agric Environ Med. 2012; 19(4): 723-731.

16. Bartoszcze-Tomaszewska M, Tomaszewski T, Stodółkiewicz A, Koliński P, Dobieżyńska B. Urazy czaszki twarzowej powstałe podczas pracy w rolnictwie w rejonie środkowowschodnim polski (część I). Wiad Lek. 2004; LVII 5-6(7-8): 301-305.

17. Kalinowski P, Czerska B. Epidemiologia urazów wśród hospitalizowanych w 2006 roku w 6. Szpitalu Wojskowym w Dęblinie. Probl Hig Epidemiol. 2007; 88(4): 455-460.

18. Baczuk L. Urazy u osób w wieku starszym. Post Nauk Med. 2008; 12: 793-796.
19. Nogalski A, Jankiewicz L, Ćwik G, Karski J, Matuszewski Ł. Animal related injuries treated at the Department of Trauma and Emergency Medicine, Medical University of Lublin. Ann Agric Environ Med. 2007; 14: 57-61.

20. Karwat ID, Gorczyca R, Krupa S. Causes and consequences of head injuries among rural population hospitalized in the Ward for MultiOrgan Injuries. I. Demographic and social structure. Ann Agric Environ Med. 2009; 16: 15-22.

21. Karwat ID, Krupa S, Gorczyca R. Causes and consequences of head injuries among rural inhabitants hospitalised in a multi-organ injury ward. II. Circumstances, types and consequences of head injuries. Ann Agric Environ Med. 2009; 16: 23-29.

22. Stevenson J. When the trauma patient is elderly. J of PeriAnesth Nurs. 2004; 19: 392-400.

23. Chang TT, Schecter WP. Injury in the elderly and end-of-life decisions. Surg Clin N Am. 2007; 87: 229-245.

24. Zagórski J, Filip RS. Age- and BMD-related differences in biochemical markers of bone metabolism in rural and urban women from Lublin Region, Poland. Ann Agric Environ Med. 2004; 11(2): 255-259.

25. Filip RS, Zagórski J. Bone mineral density and osteoporosis in rural and urban women. Epidemiological study of the Lublin Region (eastern Poland). Ann Agric Environ Med. 2001; 8(2): 221-227.

26. Filip RS, Zagórski J. Osteoporosis risk factors in rural and urban women from the Lublin Region of Poland. Ann Agric Environ Med. 2005; 12(1): 21-26.

27. Sygit K, Nasiłowska-Barud A, Karwat ID, Gorczyca R, Jędrych M, Kołłątaj W. Selected social and health problems in functioning of disabled rural and urban inhabitants in the Lublin region - similarities and differences. Ann Agric Environ Med. 2010; 17: 287-299.

28. Springer M, Wybraniec-Lewicka B, Czerwiak G, Michalska M, Krawczyńska J. Upadki i urazy wieku geriatrycznego. Stud Med. 2008; 9: 77-81.

29. Wysocka B, Ślusarz R, Haor B. Epidemiologia urazów kręgosłupa w materiale własnym Pogotowia Ratunkowego we Włocławku: Badania retrospektywne. Piel Neurol i Neurochir. 2012; 1(3): 109-118. 